\title{
Glomus coccygeum in pilonidal sinus surgical specimens: report of two rare cases with special reference to SOX10 expression
}

\author{
Stanislav Philipov ${ }^{1}$ (D) , Ivan Maslarski ${ }^{1}$ (D), Mariya Koleva-Ivanova ${ }^{2}$ (D), Dorian Dikov $^{1-3}$ (D) \\ ${ }^{1}$ Department of Anatomy, Histology, Pathology and Forensic Medicine, Medical Faculty at the University of Sofia, St. Kliment Ohridski, Bulgaria \\ ${ }^{2}$ Department of General and Clinical Pathology, Medical University of Plovdiv, Filibe, Bulgaria \\ ${ }^{3}$ Service d'Anatomie et de Cytologie Pathologiques, Grand Hôpital de l'Est Francilien, Fossigny, Paris, France
}

\begin{abstract}
We report two new cases of glomus coccygeum in pilonidal sinus excision specimens. The positive expression of glomus coccygeum cells for SOX10 is used for the first time. SOX10 is a useful immunohistochemical marker for identifying this microanatomical structure, confirming the diagnosis and may help the differential diagnosis. The glomus coccygeum cells are probably neural crest-derived from multipotent Schwann cell precursors.
\end{abstract}

Keywords: glomus coccygeum; pilonidal sinus; SOX10; vestigial structure; sacral area

Anatomy 2020;14(3):216-219 @2020 Turkish Society of Anatomy and Clinical Anatomy (TSACA)

\section{Introduction}

Glomus bodies (including coccygeal glomus) consist of modified smooth muscle cells arranged in layers around small vascular channels. ${ }^{[1]}$ They are a modified arteriovenous anastomosis in which innervation is similar to the canals of Sucquet-Hoyer of the distal phalanges of the toe. ${ }^{[2]}$ When found in distal extremities, they generally do not represent a diagnostic problem.

The glomus coccygeum (GC) is a vestigial structure in the deep layers of the skin that is removed from the lumbosacral region. Its function in this area is still unknown. ${ }^{[3]}$

The GC may be an incidental finding in the tissue surrounding a pilonidal sinus cyst in surgical specimens. ${ }^{[4]}$ The frequency of this topographic combination is low with only 11 cases (including our two cases) reported in the English literature. ${ }^{[3-5]}$ It may represent a diagnostic challenge to the surgical pathologist. ${ }^{[2,5,6]}$

Immunohistochemically, the glomus cells express smooth muscle actin (SMA), vimentin, neuron-specific enolase (NSE) but do not express desmin, S100 protein or endothelial cell markers: CD31 and FVIIIR: Ag. Both S100-positive (nerve sheath) cells and CD31/FVIIIR: Agpositive endothelial cells are typically present within the glomus body. ${ }^{[7]}$

The SOX10 transcription factor is known to be important in the development and maintenance of the peripheral nervous system. ${ }^{[8,9]}$ The SOX10 nuclear protein is widely expressed in glial cells, melanocytes, Schwann cells, and myoepithelial cells. ${ }^{[10]}$ To our knowledge, SOX10 has not been reported in GC in the medical literature so far.

\section{Case Report}

Case 1 was a 20-year-old man presented with symptoms of a pilonidal sinus cyst. Grossly, the local excision surgical specimen was $6 \times 1 \times 3 \mathrm{~cm}$ in size and contained a cyst with diameter of $1.8 \mathrm{~cm}$.

Case 2 was a 45 -year-old woman presented with an infected cutaneous lesion for 6 months with a recurrent abscess. Grossly, the cutaneous fragment was $2.5 \times 1.5 \times 1$ 
$\mathrm{cm}$ in size, the surface of which was raised by a $1.5 \mathrm{~cm}$ cyst, with a creamy content.

Histological examination of both lesions showed the presence of a pilonidal sinus cyst. In both specimens, when a deep cut section of the fragments was done, glomus structures measuring $0.3 \mathrm{~cm}$ (case 1) and $0.5 \mathrm{~cm}$ (case 2) along the long axis were found. The lesions were recognized as sharply circumscribed complex structures composed of clusters and nests of small to medium-sized epitheloid cells associated with small vascular channels and with small nerve bundles (Figure 1a).

Immunohistochemistry of both lesions showed that glomus cells expressed SMA (Figure 1b), NSE and vimentin and were negative for desmin, cytokeratin, CD31 and CD34 (data not shown) and S100 protein (Figure 2a). Proliferative activity was low. Besides, in both cases, SOX10 - staining was presented in cellular nuclei of most of glomus cells (Figure $2 \mathbf{b}$ ). The H-score was used for the interpretation of the SOX10 expression. ${ }^{[8]}$ The median $\mathrm{H}$-score for SOX10 in both cases of GC was 50 (40-60) (a marker was considered positive when its $\mathrm{H}$-score was $\geq 10)$. ${ }^{[8]}$

\section{Discussion}

The GC is a non-pathologic structure that exhibits significant variations in size and proportion ofits constitutive elements. It is presented in every completely excised specimen of the coccyx. ${ }^{[1]}$ This structure is composed of modified smooth muscle cells (glomus cells) arranged in concentric layers around blood vessels. ${ }^{[1,2]}$ Immunohistochemical expression of SMA and NSE in glomus cells may be beneficial for accurate identification of a diagnosis. The results we have obtained for PS100- /SOX10+ immunophenotype of GC-cells support the fact that they are neural crestderived, similar to glomus cells in the carotid body. ${ }^{[3]}$ The very close association of these cells with Schwann cells probably supports their origin from multipotent Schwann cell precursors. $^{[3,4]}$

Our observation contains a practical aspect in the differential diagnosis of normal or hyperplastic GC versus glomus tumor and paraganglioma. In the latter cases, SOX10 is not expressed or expressed only in the sustentacular cells, but not in the tumor cells. Apart from that, they originate from the neural crest, the positive spectrum of SOX10 in GC can probably be explained by the available myoepithelial component in these structures, which is also SOX10 positive. The lack of expression of SOX10 in the glomus tumor may be due to a P46S mutation which is not available in normal or hyperplastic GC. ${ }^{[1]}$
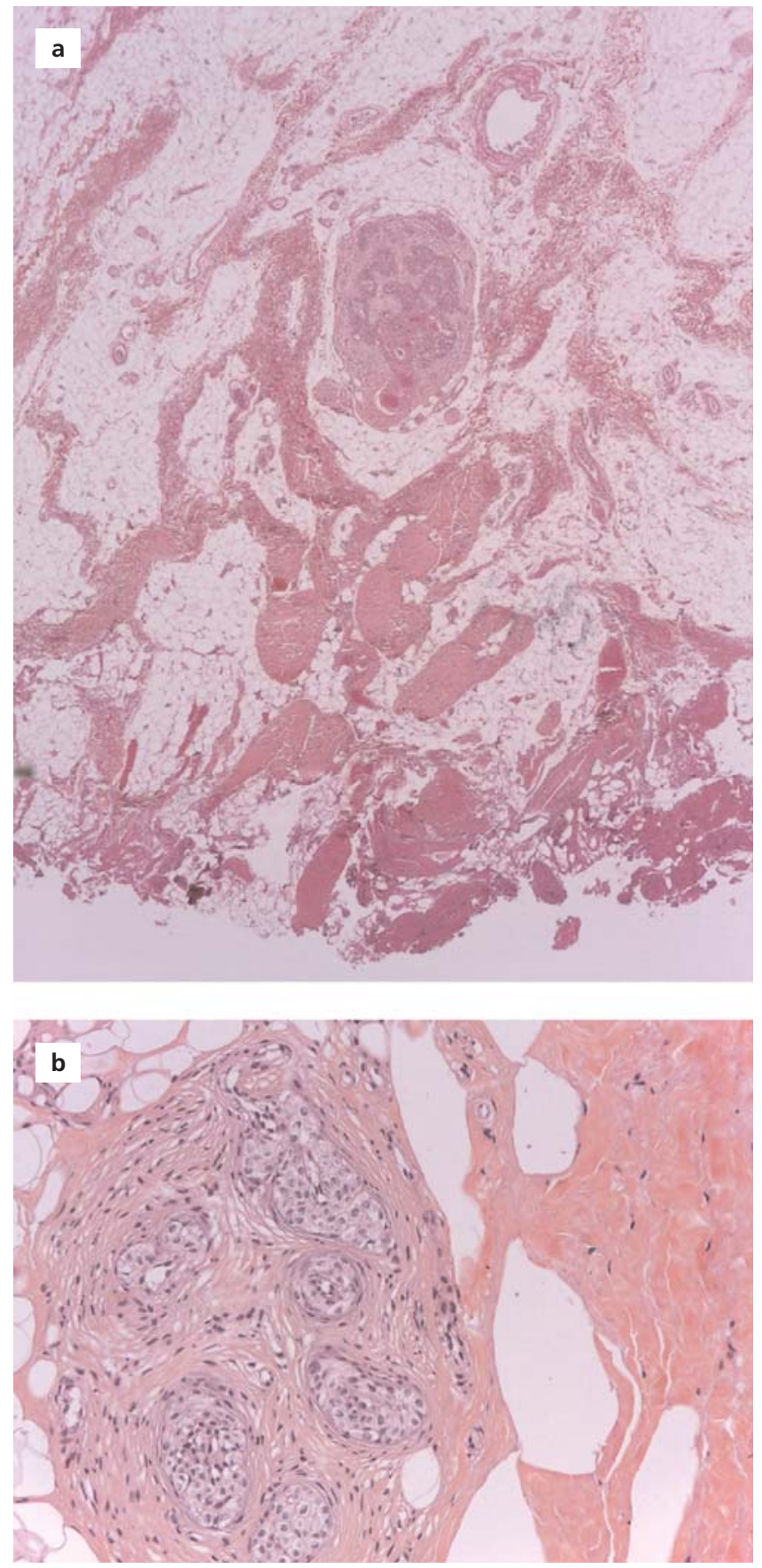

Figure 1. Sections stained with hematoxylin-eosin-saffron (HES) showing a sharply circumscribed complex structure (glumus body) situated deep in the connective tissue. (a) Case 1 with clusters and nests of small to medium-sized epitheloid cells associated with a small vascular channel, $\times 25$ magnification; (b) Case 2, ×200 magnification.

In conclusion, we describe two new cases of the GC in pilonidal sinus excision specimens. SOX10 is a helpful marker for identifying this microanatomical structure and confirming the diagnosis. Adding our two cases to the lit- 

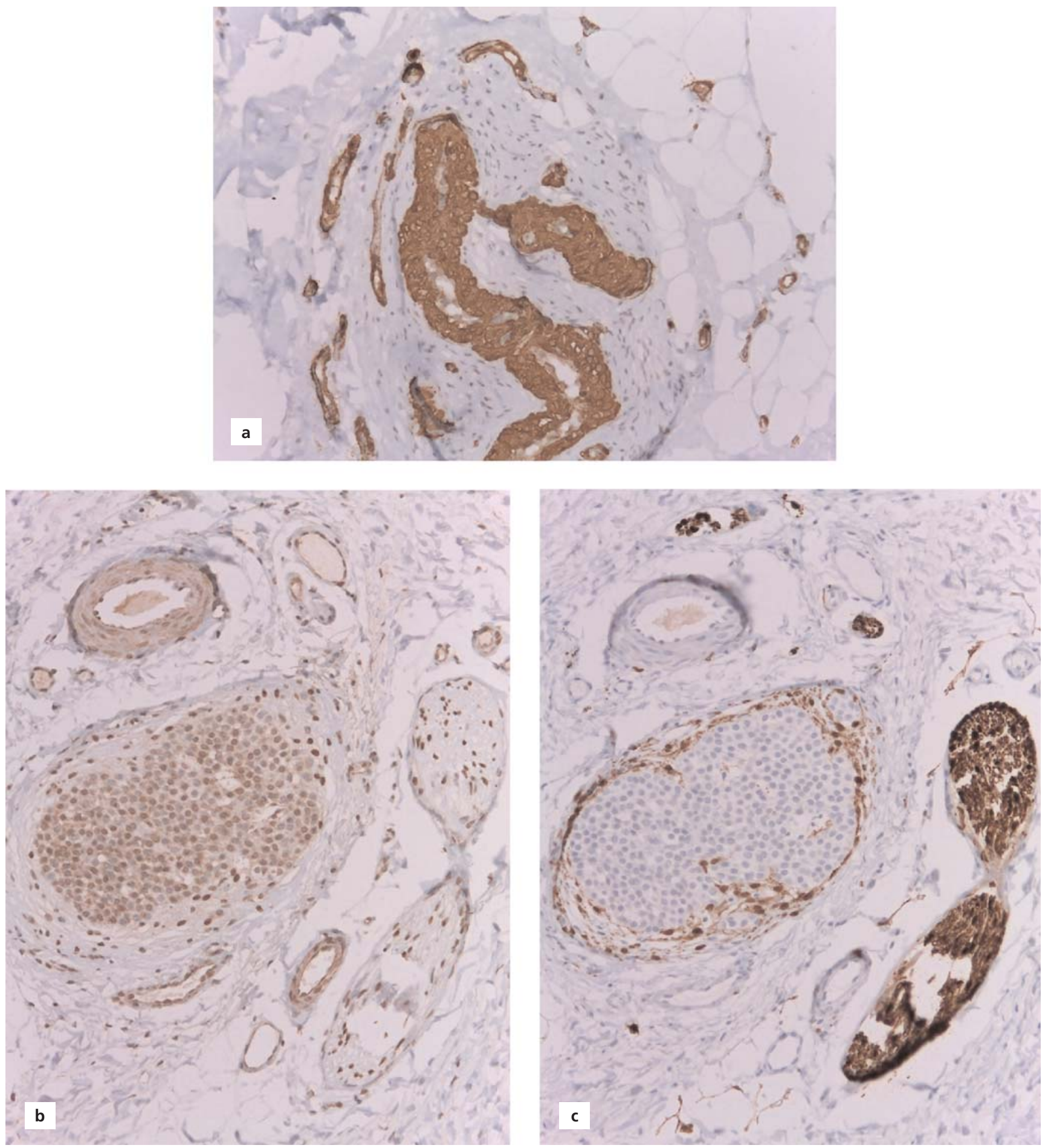

Figure 2. Immunohistochemical staining of glomus cells for smooth muscle actin. (a) Case 1, x200 magnification; (b) hyperplastic glomus cells lack expression of S100 protein; note S100 protein accentuated peripheral Schwann cells (Case 2), ×100 magnification; (c) glomus cells show variable intensity of SOX10 intranuclear staining (Case 2), ×100 magnification.

erature provides novel clinicopathological data, useful for precise diagnosis and avoids confusion with glomus tumors in the sacral area. To the best of our knowledge, the posi- tive expression of GC- cells for SOX10 is used for the first time as a reliable immunohistochemical marker that may aid the diagnosis and the differential diagnosis. 


\section{Conflict of Interest}

The authors declare no conflict of interest.

\section{Author Contributions}

SP: evaluation of the cases, writing the manuscript; IM: design of the study; MKI: writing the manuscript; DD: design of the study, supervision, critical revision of the manuscript.

\section{Ethics Approval}

The study was performed following the aid of the ethical standards down in the 1964 Declaration of Helsinki and its later amendments. Written and signed consent was obtained from the patients.

\section{Funding}

The authors received no financial support for this study.

\section{References}

1. Hockman D, Adameyko I, Kaucka M, Barraud P, Otani T, Hunt A, Hartwig AC, Sock E, Waithe D, Franck MCM, Ernfors P, Ehinger S, Howard MJ , Brown N, Reese J, Baker CVH. Striking parallels between carotid body glomus cell and adrenal chromaffin cell development. Dev Biol 2018;444:S308-S324.

2. Albrecht $\mathrm{S}$, Zbieranowski I. Incidental glomus coccygeum: when a normal structure looks like a tumor. Am J Surg Pathol 1990;14:922_ 4.

ORCID ID:

S. Philipov 0000-0003-2467-7561;

I. Maslarski 0000-0001-7126-9232; M. Koleva-Ivanova 0000-0002-2014-7435 D. Dikov 0000-0002-2404-7538

deomed。
3. Bisceglia M, Bisceglia S, Ciampi C, Panniello G, Galliani C. Glomus coccygeum: a review. Pathologica 2018;110:287-93.

4. Rahemtullah A, Szyfelbein K, Zembowicz A. Glomus coccygeum: report of a case and review of the literature. Am J Dermatopathol 2005;27:497-9.

5. Santos LD, Chow C, Kennerson AR. Glomus coccygeum may mimic glomus tumour. Pathology 2002;34:339-43.

6. Gatalica Z, Wang L, Lucio ET, Miettinen M. Glomus coccygeum in surgical pathology specimens: small troublemaker. Arch Pathol Lab Med 1999;123:905-8.

7. Miettinen M, McCue PA, Sarlomo-Rikala M, Bernat W, Czapiewski P, Kopczynski J, Thompson LD, Lasota J, Wang Z, Fetsch JF. Sox10--a marker for not only schwannian and melanocytic neoplasms but also myoepithelial cell tumors of soft tissue: a systematic analysis of 5134 tumors. Am J Surg Pathol 2015;39:826-35.

8. Conti A, Maestroni GJ, Cosentino M, Frigo GM, Lecchini S, Marino F, Bombelli R, Ferrari M, Brivio F, Roselli MG, Lissoni P. Evidence for a neuroimmunomodulatory and a hematopoietic role of the Luschka's coccygeal body (3). Neuro Endocrinol Lett 2000;21:391403.

9. Maggiani F, Kashima T, Simon J, Athanasou NA. Immunophenotypic analysis of glomus coccygeum associated with coccygodynia. Skeletal Radiol 2011;40:1455-9.

10. Karamchandani JR, O Nielsen T, van de Rijn M, West RB. Sox10 and $\mathrm{S} 100$ in the diagnosis of soft-tissue neoplasms. Appl Immunohistochem Mol Morphol 2012;5:445-50.

11. Davis J, Petterson M, Newell J, Lauwers GY, Royce T, Demeure MJ. Micrometastatic gastric glomus tumour confirmed by next-generation sequencing. Histopathology 2018;72:351-4.

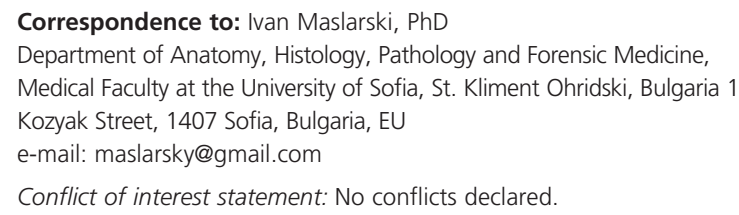

This is an open access article distributed under the terms of the Creative Commons Attribution-NonCommercial-NoDerivs 4.0 Unported (CC BY-NCND4.0) Licence (http://creativecommons.org/licenses/by-nc-nd/4.0/) which permits unrestricted noncommercial use, distribution, and reproduction in any medium, provided the original work is properly cited. How to cite this article: Philipov S, Maslarski I, Koleva-Ivanova M, Dikov D. Glomus coccygeum in pilonidal sinus surgical specimens: report of two rare cases with special reference to SOX10 expression. Anatomy 2020;14(3):216-219. 